\title{
PEMANFAATAN Bacillus subtilis dan Pseudomonas fluorescens DALAM PENGENDALIAN HAYATI Ralstonia solanacearum PENYEBAB PENYAKIT LAYU BAKTERI PADA TOMAT
}

\section{UTILIZATION OF Bacillus subtilis and Pseudomonas fluorescens IN BIOLOGICAL CONTROL OF Ralstonia solanacearum THE CAUSE OF BACTERIAL WILT DISEASE IN TOMATO}

\author{
Istiqomah dan Dian Eka Kusumawati
}

Universitas Islam Darul ‘Ulum Lamongan, Jalan Airlangga 03 Sukodadi, Lamongan, Jawa Timur

Korespondensi : istiqomah@unisda.ac.id / istiqomah.faqih@gmail.com

Diterima 4 April 2018 / Disetujui 26 Juni 2018

\begin{abstract}
ABSTRAK
Salah satu penyakit penting pada produksi tomat di Indonesia adalah layu bakteri yang disebabkan oleh Ralstonia solanacearum. Alternatif untuk mengendalikan penyakit layu bakteri adalah dengan menggunakan Bacillus subtilis dan Pseudomonas fluorescens. Tujuan penelitian ini untuk mengetahui kemampuan $B$. subtilis dan $P$. fluorescens dalam mengendalikan penyakit layu bakteri yang disebabkan $R$. solanacearum serta mekanisme penghambatannya. Penelitian ini terdiri dari 5 tahap, yaitu perbanyakan inokulum $R$. solanacearum, uji virulensi dan uji hipersensitif $R$. solanacearum, uji antagonis $B$. subtilis dan $P$. fluorescens terhadap $R$. solanacearum pada media agar, uji jenis antibiosis, penelitian di rumah kaca, dan analisis total fenol. Hasil penelitian uji antagonis menunjukkan bahwa semua isolat $B$. subtilis dan $P$. fluorescens memiliki potensi menghambat $R$. solanacearum dengan tipe antibiosis bakteriostatik. Hasil analisis kadar fenol menunjukkan bahwa terjadi peningkatan total fenol secara signifikan pada tanaman tomat yang diaplikasikan isolat $B$. subtilis UB-ABS6, $P$. fluorescens UB-PF5 dan P. fluorescens UB-PF6. Penelitian di rumah kaca menunjukkan bahwa semua tanaman tomat yang diaplikasikan agens hayati mengalami penundaan masa inkubasi dibandingkan dengan kontrol. Isolat $B$. subtilis UB-ABS2, $B$. subtilis UB-ABS6, $P$. fluorescens UB-PF5 dan $P$. fluorescens UB-PF6 secara signifikan menekan kejadian penyakit layu bakteri berturut-turut 50\%, 30\%,60\%, dan 60\%. B. subtilis dan $P$. fluorescens dapat dimanfaatkan untuk mengendalikan layu bakteri pada tomat yang disebabkan oleh Ralstonia solanacearum.
\end{abstract}

Kata kunci : Bacillus subtilis, pengendalian hayati, Pseudomonas fluorescens, Ralstonia solanacearum, tomat.

\section{ABSTRACT}

One of important disease that infects tomato production in Indonesia is bacterial wilt disease caused by Ralstonia solanacearum. Alternative on controlling bacterial wilt is using Bacillus subtilis and Pseudomonas fluorescens. Goal of the research was to find out ability of $B$. subtilis and $P$. fluorescens to control $R$. Solanacearum and mechanism of the inhibition. This

Cyte this as: Istiqomah \& Kusumawati, D. E. (2018). Pemanfaatan Bacillus subtilis dan Pseudomonas fluorescens dalam pengendalian hayati Ralstonia solanacearum penyebab penyakit layu bakteri pada tomat. Jurnal Agro, 5(1), 1-12. https://doi.org/10.15575/2305 
research divided into 5 stages, i.e. propagation of $R$. solanacearum, virulence and hypersensitive tests of $R$. Solanacearum, antagonist test of $B$. subtilis and $P$. fluorescens against $R$. solanacearum on agar medium, antibiosis type test, research in greenhouse, and total phenol analysis. The result showed that all isolates of $B$. subtilis and $P$. fluorescens have potential to inhibite $R$. solanacearum by bacteriostatic antibiosis type. The total phenol level showed significant increase of phenol on tomato along with the application of isolates $B$. subtilis UB-ABS6, $P$. fluorescens UB-PF5 and $P$. fluorescens UB-PF6. Research in the greenhouse showed that all tomatoes, which had been given bioagent, did delay on the incubation than the control. Isolates of $B$. subtilis UB-ABS2, B. subtilis UB-ABS6, $P$. fluorescens UB-PF5, and $P$. fluorescens UB-PF6 had significantly inhibited the bacterial wilt disease $50 \%, 30 \%, 60 \%$, and $60 \%$, respectively. Therefore, $B$. subtilis and $P$. fluorescens can be used to control bacterial wilt diseases on tomato caused by Ralstonia solanacearum.

Keywords : Bacillus subtilis, bio-control, Pseudomonas fluorescens, Ralstonia solanacearum, tomato.

\section{PENDAHULUAN}

Tomat merupakan komoditas hortikultura yang penting di Indonesia dan berperan strategis dalam pemenuhan kebutuhan masyarakat sehari-hari. Selama masa pertumbuhannya, tomat mengalami beberapa kendala budidaya baik dari hama maupun patogen yang dapat menurunkan produksi. Kendala utama dalam meningkatkan produksi tomat adalah serangan hama dan penyakit. Menurut Agrios (2005), kerugian panen akibat penyakit ini diperkirakan sekitar $14 \%$ di seluruh dunia.

Salah satu penyakit penting pada tanaman tomat adalah layu bakteri yang disebabkan oleh Ralstonia solanacearum. Di benua Amerika, penyakit ini mampu menurunkan tingkat produksi pada $15 \%$ lahan di Carolina Selatan (Agrios, 2005). Menurut Rivard et al. (2012), pada lahan yang terinfestasi $R$. solanacearum secara alami di Jerman kejadian penyakit ini mencapai $75 \%$. Patogen $R$. solanacearum mengganggu pengangkutan air dan zat makanan dengan jalan merusak sel tanaman. Enzim yang berperan dalam proses ini adalah enzim selulase dan pektinase. Enzim ini menghancurkan dinding sel tanaman yang mengandung selulosa dan pektin. Akibat dari serangan ini terjadi penyimpangan fisiologis tanaman yaitu terganggunya proses translokasi air dan nutrisi lainnya sehingga tanaman menjadi layu kemudian mati (Agrios, 2005).

Berbagai upaya telah dilakukan dalam pengendalian penyakit layu bakteri, diantaranya adalah penggunaan benih bebas hama dan penyakit, penanaman jenis tanaman yang tidak sejenis, penanaman yang tidak serempak pada lahan yang luas, dan penggunaan pestisida sintetis, tetapi cara ini belum mendapatkan hasil yang memuaskan. Alternatif pengendalian lain untuk mengendalikan penyakit layu bakteri adalah dengan pengendalian hayati menggunakan mikroba. Penggunaan agens hayati dalam pengendalian penyakit tanaman memiliki beberapa kelebihan diantaranya dapat mengurangi pencemaran lingkungan bahan kimia dari insektisida, lebih efisien, berkelanjutan, tidak merusak keragaman hayati, dan kompatibel dengan cara pengendalian lainnya (Setiati et al., 2016). Bakteri yang dapat berfungsi sebagai agens 
hayati adalah Bacillus subtilis dan Pseudomonas fluorescens.

Bakteri B. subtilis dan $P$. fluorescens telah dikenal secara luas memiliki potensi sebagai agens hayati untuk menghambat beberapa patogen tanaman. Pseudomonas spp. adalah kelompok bakteri perakaran yang efektif menekan berbagai penyakit tanaman diantaranya rebah semai, busuk lunak, layu bakteri, dan lain-lain pada banyak varietas tanaman. Zat antibiotik yang diproduksi oleh Pseudomonas spp. (2,4-diacetylphloroglucinol / 2,4-DAPG) mampu meningkatkan ketahanan tanah terhadap patogen (Weller et al., 2012). Penelitian Chen et al. (2013) yang di lakukan di rumah kaca membuktikan bahwa $B$. subtilis memiliki sifat yang mampu menekan berbagai jenis patogen tanaman dan mampu bertahan pada kondisi lingkungan yang ekstrim.

Kemampuan kedua bakteri ini dalam meningkatkan pertumbuhan dan pengendalian penyakit pada berbagai komoditas telah banyak diteliti, tetapi informasi yang lengkap mengenai potensi dan karakter $B$. subtilis dan $P$. fluorescens sebagai pengendali hayati dalam menekan patogen penyebab penyakit tanaman dan meningkatkan kandungan senyawa pertahanan tanaman (fenol) pada tanaman tomat belum banyak diteliti secara menyeluruh, terutama di Indonesia. Penelitian ini dilakukan untuk mengetahui kemampuan $B$. subtilis dan $P$. fluorescens dalam mengendalikan penyakit layu bakteri (R. Solanacearum) dan mengetahui mekanisme penghambatannya di laboratorium dan pada tanaman tomat.

\section{BAHAN DAN METODE}

Penelitian dilaksanakan di rumah kaca Jurusan Hama dan Penyakit Tumbuhan dan di Laboratorium Penyakit Tumbuhan, Sub Laboratorium Bakteriologi, Program Studi Agroekoteknologi, Fakultas Pertanian Universitas Brawijaya. Waktu pelaksanaan penelitian pada bulan April - Juli 2017.

Perbanyakan Inokulum Patogen $\boldsymbol{R}$. solanacearum, B. subtilis, dan $P$. fluorescens

Isolat patogen $R$. solanacearum, $B$. subtilis, dan $P$. fluorescens didapatkan dari koleksi Laboratorium Penyakit Tumbuhan Jurusan Hama Penyakit Tumbuhan Fakultas Pertanian Universitas Brawijaya. Isolat $B$. subtilis yang digunakan adalah kode UBABS2 dan UB-ABS6. Isolat $P$. fluorescens yang digunakan adalah kode UB-PF5 dan UB-PF6. Pemurnian bakteri dilakukan dengan streak koloni tunggal pada media NA (Nutrient agar) kemudian diperbanyak dengan menggoreskan koloni tunggal pada media NA yang baru.

Pengamatan Mikroskopis, Uji Hipersensiitif (HR) dan Uji Patogenesitas R. solanacearum

Pengamatan mikroskopis dilakukan untuk mengidentifikasi isolat $R$. solanacearum termasuk ciri-ciri koloni virulen atau avirulen. Identifikasi dilakukan berdasarkan Champoiseau et al. (2009) yaitu ciri-ciri koloni $R$. solanacearum yang virulen adalah setelah 2 hari pada media Kelman's Tetrazolium Chloride (TZC) agar koloni berbentuk besar, bulat tidak teratur, cembung, fluidal dan tepi koloni berwarna putih dengan bagian tengah berwarna merah. Sedangkan koloni yang tidak virulen berbentuk bulat tidak teratur, ukuran lebih 
kecil dan berwarna merah keseluruhan. Pengamatan dilakukan di bawah mikroskop dengan perbesaran 4,5x.

Uji HR dilakukan dengan melukai permukaan daun tembakau bagian bawah menggunakan jarum suntik aseptik kemudian suspensi $R$. solanacearum diinfiltrasikan menggunakan spet tanpa jarum suntik. Suspensi yang digunakan adalah biakan murni $R$. solanacearum yang berumur 48 jam dengan kerapatan $10^{9} \mathrm{CFU}$ $\mathrm{mL}^{-1}$. Pengamatan dilakukan 24-72 jam setelah inokulasi hingga terjadinya nekrotik pada daun.

Uji patogenesitas dilakukan dengan membuat suspensi biakan murni $R$. solanacearum yang berumur 48 jam

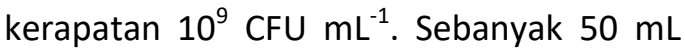
suspensi bakteri disiramkan pada akar tanaman tomat varietas Permata berumur 1 bulan yang akarnya telah dilukai terlebih dahulu dengan menggunakan pisau aseptik. Selanjutnya dilakukan pengamatan terhadap gejala serangan penyakit layu bakteri yang muncul pada tanaman tomat.

\section{Uji Antagonis B. subtilis dan P. fluorescens terhadap $R$. solanacearum pada Media Agar}

Uji antagonis dilakukan dengan metode pengkabutan menurut Kawaguchi et al. (2008). Biakan murni dari semua isolat $B$. subtilis dan $P$. fluorescens yang berumur 48 jam dibuat suspensi hingga kerapatan $10^{9}$ CFU $\mathrm{mL}^{-1}$ dalam akuades steril. Potongan kertas saring steril diameter $5 \mathrm{~mm}$ dimasukkan ke dalam suspensi bakteri selama \pm 1 menit dan ditiriskan selama 2 jam. Kertas saring yang sudah kering ditanam pada media NA pada cawan Petri yang berdiameter $9 \mathrm{~cm}$ dan diinkubasi selama 2 hari. Setelah dinkubasi kemudian diberi khloroform pada tutup cawan Petri dalam keadaan dibalik selama 1 jam. Setelah itu biakan dikabutkan dengan suspensi bakteri $R$. solanacearum dengan

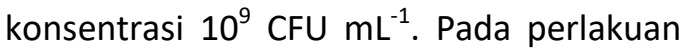
kontrol kertas saring hanya direndam dalam aquades steril. Seluruh perlakuan diinkubasi selama 2 hari dan daerah zona bening diukur dengan menggunakan jangka sorong.

\section{Uji jenis Antibiosis B. subtilis dan $P$.}

\section{fluorescens}

Bagian zona bening di sekitar kertas saring pada hasil uji antagonis diambil dan dimasukkan dalam tabung reaksi yang berisi $10 \mathrm{~mL}$ media pepton cair 10\% kemudian digojlok selama 24 jam. Apabila berubah menjadi keruh maka tipe antibiosisnya adalah bakteriostatik. Apabila media tetap jernih maka tipe antibiosisnya adalah bakterisidal (Djatmiko et al., 2007).

\section{Penelitian Rumah Kaca}

Media tanam campuran tanah : kompos (1:1) disterilkan menggunakan formalin $4 \%$ dan ditutup plastik selama 7 hari. Tanah dikeringanginkan selama 7 hari dan siap digunakan sebagai media tanam. Polybag diisi media tanam sebanyak $3 \mathrm{~kg}$ dan ditanami bibit tomat varietas Permata yang berumur 14 hari kemudian suspensi $B$. subtilis dan $P$. fluorescens sebanyak $20 \mathrm{~mL}$

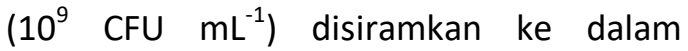
polybag. Inokulasi $R$. solanacearum dilakukan 24 jam setelah aplikasi $B$. subtilis dan P. fluorescens (Huang et al., 2013). Aplikasi dilakukan dengan cara melukai akar tanaman tomat menggunakan pisau aseptik kemudian sebanyak $20 \mathrm{~mL}$ suspensi $R$. solanacearum dengan kerapatan $10^{9}$ CFU $\mathrm{mL}^{-1}$ disiramkan di sekitar perakaran yang telah dilukai. Kejadian penyakit dan 
efektifitas penekanannya dihitung menggunakan rumus sebagai berikut :

Kejadian penyakit $=$ (jumLah tanaman terserang / total seluruh tanaman) x 100 Efektifitas penekanan kejadian penyakit = [(kejadian penyakit pada kontrol - kejadian penyakit pada perlakuan)/kejadian penyakit pada kontrol] x 100

\section{Analisis Total Fenol}

Sampel yang digunakan untuk analisis total fenol adalah bagian daun tomat. Pengambilan sampel dilakukan 7 HSI (Hari Setelah Inokulasi) $R$. solanacearum. Kandungan total fenol dianalisis berdasarkan metode Folin-Ciocalteu dengan katekol sebagai standar (Sharma et al., 2011). Daun sebanyak 0,5 g diekstraksi dengan nitrogen cair dan $5 \mathrm{~mL}$ etanol, hasil ektraksi dimasukkan ke dalam tabung 1,5 $\mathrm{mL}$ kemudian disentrifugasi $10.000 \mathrm{rpm}$ selama 20 menit, ekstraksi diulangi lagi dengan etanol $80 \%$, perbandingan volume etanol dan hasil ektraksi adalah 1:1. Supernatan yang dihasillkan dievaporasi hingga kering dalam waterbath dengan suhu $78^{\circ} \mathrm{C}$. Pada residu yang tersisa ditambahkan akuades hingga mencapai volume $3 \mathrm{~mL}$ dan reagen Folin-Ciocalteu sebanyak 0,5 $\mathrm{mL}$ kemudian letakkan pada waterbath yang mendidih selama 1 menit. Tabung didinginkan dan hasil dibaca dengan spektofotometer $650 \mathrm{~nm}$. Larutan standar yang digunakan adalah katekol. Hasil konsentrasi fenol dinyatakan sebagai $\mathrm{mg} \mathrm{g}^{-1}$.

\section{Analisis Statistik}

Penelitian di laboratorium dilakukan menggunakan Rancangan Acak Lengkap (RAL) dengan 5 perlakuan dan 5 ulangan sedangkan penelitian rumah kaca menggunakan Rancangan Acak Kelompok
(RAK) dengan 6 perlakuan dan 4 ulangan. Data dianalisis menggunakan analisis sidik ragam (ANOVA), jika terdapat perbedaan yang signifikan maka dilanjutkan menggunakan uji Duncan pada taraf $5 \%$. Pada data yang berbentuk persentase maka terlebih dahulu ditransformasikan menggunakan arcussin $+0,5$.

\section{HASIL DAN PEMBAHASAN}

Virulensi, daya Hipersensiitif (HR) dan Patogenesitas $R$. solanacearum

Hasil pengamatan morfologi diperoleh bakteri $R$. solanacearum setelah masa inkubasi berbentuk bulat tidak teratur, berwarna putih keruh, dan terdapat warna merah muda di bagian tengahnya, tepian rata, elevasi cembung, dan mucoid. Berdasarkan hasil pengamatan maka isolat $R$. solanacearum adalah termasuk ciri isolat virulen. Hal ini sesuai dengan pernyataan Champoiseau et al. (2009) bahwa ciri koloni virulen memiliki bentuk besar, bulat tidak teratur, cembung, fluidal, dan tepi koloni berwarna putih dengan bagian tengah berwarna merah. Sedangkan koloni yang tidak virulen berbentuk bulat tidak teratur, ukuran lebih kecil, dan berwarna merah keseluruhan. Hasil pengamatan mikroskopis dapat dilihat pada Gambar 1.

Hasil uji hipersensitif yang dilakukan pada tanaman tembakau berumur 1 bulan menunjukkan adanya reaksi positif terhadap $R$. solanacearum. Suspensi patogen yang diinfiltrasikan pada permukaan bawah daun tembakau menyebabkan daun nekrosis atau menguning. Gejala awal yang muncul adalah jaringan daun tembakau berubah menjadi lebih terang kemudian mengering. Nekrosis muncul pada bagian daun yang di 
dalam jaringannya tersebar suspensi $R$. solanacearum. Gejala nekrotik muncul 4872 jam setelah inokulasi. Hal ini sesuai dengan penelitian yang dilakukan oleh Wahyudi et al. (2011), yang menyatakan bahwa hasil uji hipersensitif positif adalah daun tembakau menjadi kecoklatan pada area masuknya bakteri. Reaksi ini paling jelas teramati 48 jam setelah penyuntikan.

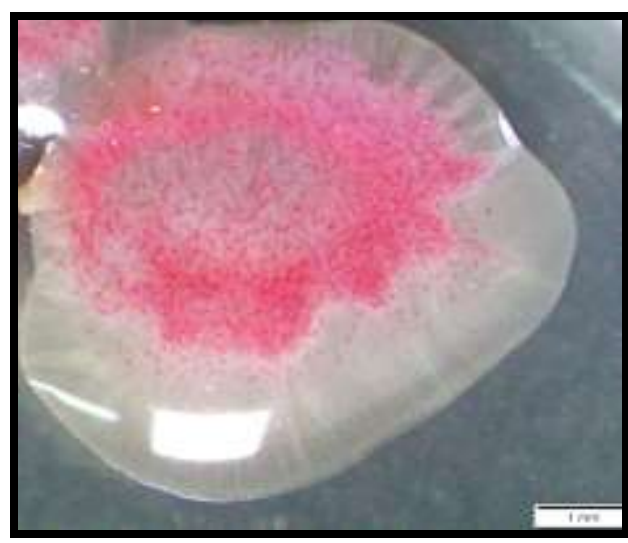

Gambar 1. Koloni R. solanacearum pada media TZC dengan perbesaran mikroskop $4,5 x$

Proses kematian lokal pada jaringan tanaman diawali dengan pengenalan oleh tanaman terhadap sinyal molekul (elisitor) yang diproduksi oleh patogen. Nukleus bergerak menuju patogen yang menyerangnya dan segera mengalami disintegrasi. Pada saat yang hampir bersamaan butiran yang menyerupai resin berwarna coklat dalam sitoplasma berada di sekitar titik penetrasi patogen dan selanjutnya akan menyebar ke seluruh sitoplasma. Perubahan warna sel menjadi coklat akan terus berlanjut dan kematian sel akan terjadi, akibatnya patogen yang berada dalam sel akan mengalami degenerasi (Abadi, 2003). Hasil pengamatan gejala nekrotik pada uji HR dapat dilihat pada Gambar 2.

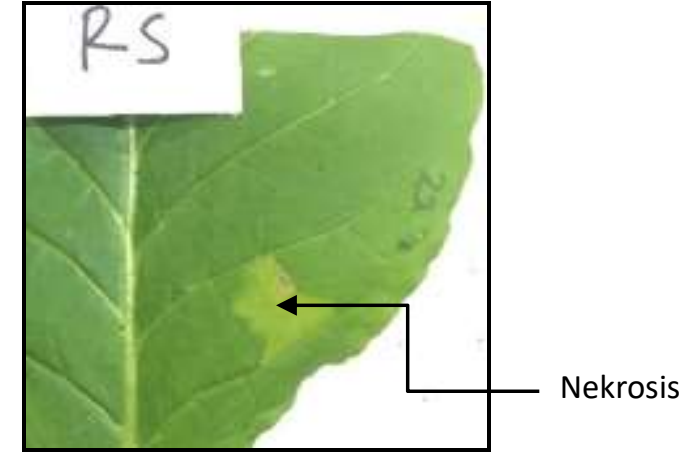

Gambar 2. Hasil uji hipersensitif pada tembakau yang diinokulasi $R$. solanacearum

Uji patogenesitas dilakukan pada tanaman tomat varietas Permata yang berumur 1 bulan. Hasil pengamatan menunjukkan bahwa tanaman tomat terserang gejala penyakit layu bakteri pada 6 hari setelah inokulasi $R$. solanacearum. Gejala penyakit ditandai dengan daun muda tanaman tomat layu permanen selanjutnya layu juga terjadi pada bagian daun yang lain. Hal ini sesuai dengan hasil penelitian Chen et al. (2013) yang menyatakan bahwa tanaman yang terserang layu bakteri mengalami gejala tangkai daun merunduk atau layu kemudian akhirnya tanaman akan mati. Hasil uji patogenesitas dapat dilihat pada Gambar 3.

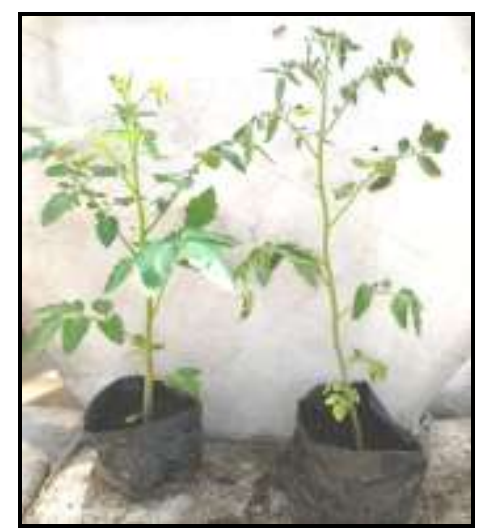

Gambar 3. Gejala serangan layu bakteri hasil uji patogenesitas ; tanaman tomat sehat pada kontrol (kiri) dan tanaman tomat bergejala layu bakteri (kanan) 
Potensi antagonis $B$. subtilis dan $P$. fluorescens terhadap $R$. solanacearum pada Uji Media Agar

Hasil analisis sidik ragam menunjukkan pengaruh yang nyata pada uji antagonisme secara in vitro antara isolat-isolat $B$. subtilis dan $P$. fluorescens terhadap $R$. solanacearum. Semua isolat $B$. subtilis dan $P$. fluorescens mampu menghasilkan zona bening (Gambar 4). Hal ini menunjukkan bahwa semua isolat yang diuji mampu menghambat perkembangan patogen $R$. solanacearum. Pada perlakuan kontrol (akuades) tidak menunjukkan adanya zona bening. Isolat UB-ABS2 dan UB-PF6 menunjukkan aktifitas penghambatan yang sama dengan perlakuan bakterisida streptomycin sulfat $20 \%$ UB-ABS6 menunjukkan aktifitas antagonis yang tertinggi dibandingkan dengan perlakuan yang lain (Tabel 1).

Tabel 1. Rerata zona bening isolat $B$. subtilis dan $P$. fluorescens terhadap $R$. solanacearum pada media agar

\begin{tabular}{|c|c|c|}
\hline Perlakuan & $\begin{array}{c}\text { Zona } \\
\text { bening } \\
(\mathrm{mm})\end{array}$ & Jenis antibiosis \\
\hline $\begin{array}{l}\text { Bakterisida } \\
\text { streptomycin } \\
\text { sulfat } 20 \%\end{array}$ & $21,16 b$ & - \\
\hline $\begin{array}{l}\text { B. subtilis UB- } \\
\text { ABS2 }\end{array}$ & $21,25 b$ & Bakteriostatik \\
\hline $\begin{array}{l}\text { B. subtilis UB- } \\
\text { ABS6 }\end{array}$ & $23,12 \mathrm{c}$ & Bakteriostatik \\
\hline $\begin{array}{l}\text { P. fluorescens } \\
\text { UB-PF5 }\end{array}$ & $19,87 \mathrm{a}$ & Bakteriostatik \\
\hline $\begin{array}{l}\text { P. fluorescens } \\
\text { UB-PF6 }\end{array}$ & $21,38 b$ & Bakteriostatik \\
\hline $\begin{aligned} \text { Keterangan : } & \text { Ar } \\
& \text { sa } \\
& \text { be } \\
& \text { Di }\end{aligned}$ & \multicolumn{2}{|c|}{$\begin{array}{l}\text { Angka yang diikuti huruf yang } \\
\text { sama tidak berbeda nyata } \\
\text { berdasarakan uji jarak berganda } \\
\text { Duncan pada taraf } 5 \% \text {. }\end{array}$} \\
\hline
\end{tabular}

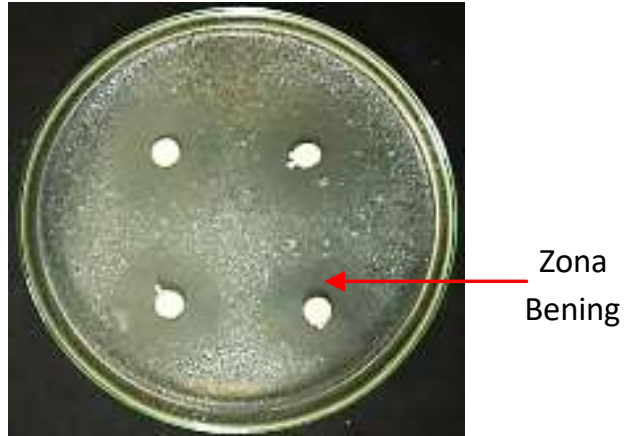

Gambar 4. Hasil uji antagonis B. subtilis UBABS6 terhadap $R$. solanacearum pada media agar. Tanda panah menunjukkan zona bening di sekitar kertas saring.

Adanya zona bening mengindikasikan bahwa isolat $B$. subtilis dan $P$. fluorescens menghasilkan metabolit sekunder yang mampu menghambat atau mematikan patogen. Mekanisme penghambatan bakteri antagonis terhadap patogen dengan cara menghasilkan berbagai senyawa metabolit anti patogen seperti siderofor, kitinase, antibiotik, sianida dan Induksi Ketahanan Sistemik (ISR). Hasil penelitian Soesanto (2008) menyatakan bahwa bakteri antagonis $P$. fluorescens dilaporkan mampu menghasilkan metabolit sekunder antara lain siderofor, pterin, pirol, dan fenazin. Siderofor dapat berperan sebagai fungistasis dan bakteriostatis. Mekanisme penekanan oleh genus Bacillus sp. melalui beberapa cara yaitu persaingan/kompetisi, antibiosis, parasitisme dan lisis (Prashar et al., 2013). Chowdhury et al. (2015) menyatakan bahwa $B$. subtilis mampu menghasilkan 68 jenis antibiotik dan $B$. brevis memproduksi 23 jenis antibiotik.

\section{Jenis Antbiosis B. subtilis dan $P$. fluorescens}

Hasil penelitian menunjukkan bahwa semua isolat $B$. subtilis dan $P$. fluorescens menghasilkan antibiosis bakteriostatik 
(Tabel 1). Larutan pepton yang ditambahkan bagian zona bening berubah menjadi keruh setelah digojlok selama 24 jam. Hal ini menunjukkan bahwa patogen $R$. solanacearum yang telah terhambat pada uji aktifitas antagonis masih mampu tumbuh kembali pada media cair pepton yang mengandung nutrisi dan tidak mengalami kematian permanen yang merupakan ciri antibiosis bakterisidal. Hal ini sesuai dengan hasil penelitian yang dilakukan oleh Djatmiko et al. (2007) yang menyebutkan bahwa zona hambat pada uji antagonisme terhadap $R$. solanacearum memiliki mekanisme penekanan secara bakteriostatik dan sifat ini dibuktikan dengan larutan pepton berwarna keruh. Bakteriostatik memberikan efek penghambatan tetapi tidak membunuh bakteri patogen. Hasil penelitian Wati et al. (2017) menunjukkan bahwa Bacillus spp. menghasilkan zona hambat terhadap patogen Xanthomonas campestris pv. Campestris dengan mekanisme bakteriostatik.

Pengaruh B. subtilis dan $P$. fluorescens terhadap Peningkatan Total Fenol Tanaman Tomat

Hasil analisis aktivitas total fenol menunjukkan bahwa peningkatan aktivitas fenol terjadi pada tanaman tomat yang diberi perlakuan $B$. subtilis dan $P$. fluorescens (Gambar 5). Aplikasi B. subtilis UB-ABS2 menunjukkan hasil yang tidak berbeda secara statistika dengan kontrol. Sementara itu, B. subtilis UB-ABS6, $P$. fluorescens UB-PF5, dan $P$. fluorescens UBPF6 menghasilkan total fenol yang lebih tinggi dibandingkan kontrol. Kandungan total fenol tertinggi dihasilkan oleh $P$. fluorescens.

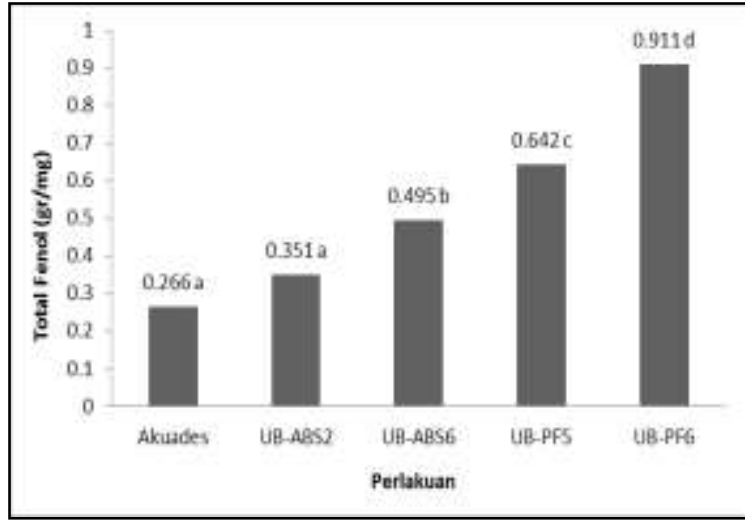

Gambar 5. Rerata total fenol pada tanaman tomat

Peningkatan total fenol merupakan salah satu indikator pengimbasan ketahanan tanaman oleh serangan patogen. Peningkatan tersebut diduga disebabkan oleh aktifitas bakteri $B$. subtilis dan $P$. fluorescens dalam jaringan tanaman. Senyawa fenol adalah hasil metabolisme tanaman yang dibentuk sebagai sistem ketahanan kimiawi tanaman untuk mencegah berkembangnya patogen tanaman (Nurcahyani et al., 2013). Menurut Agrios (2005), peningkatan metabolisme tanaman akibat infeksi patogen dan induksi ketahanan dari bakteri agens hayati yang menyebabkan peningkatan aktifitas PAL (Phenylanine Ammonia-Lyase) pada tanaman. Aktifitas PAL menyebabkan terjadinya akumulasi fenol karena fenol merupakan reaksi ketahanan tanaman yang bereaksi dengan PAL dan dioksidasi oleh Polyphenol Oksidase (PPO) dan Peroksidase (POD). Hasil penelitian Ngadze et al. (2012) menunjukkan bahwa terdapat korelasi positif antara jumlah PAL, PPO, POD, dan total fenol terhadap besarnya tingkat degradasi pektin dan resistensi tanaman terhadap penyakit. Meningkatnya kadar fenol pada tanaman dapat menginduksi ketahanan sistemik tanaman sehingga mampu menekan serangan patogen. 
Pengaruh $B$. subtilis dan $P$. fluorescens terhadap Masa Inkubasi dan Kejadian Penyakit Layu Bakteri pada Tanaman Tomat

Pada perlakuan semua isolat $B$. subtilis dan $P$. fluorescens mempengaruhi masa inkubasi, kejadian penyakit, dan efektifitas penekanan penyakit (Tabel 2). Hasil pengamatan terhadap masa inkubasi menunjukkan bahwa pada tanaman yang diberi agens hayati memiliki masa inkubasi lebih lama dibandingkan kontrol. Masa inkubasi pada perlakuan streptomycin sulfat $20 \%$ sama dengan perlakuan $B$. subtilis UB-ABS2 dan B. subtilis UB-ABS6.
Perlakuan yang menunjukkan masa inkubasi terlama adalah $P$. fluorescens UBPF5 dan P. fluorescens UB-PF6. Secara keseluruhan pemberian bakteri agens hayati mampu memperlambat masa inkubasi. Hasil penelitian Prihatiningsih et al. (2015) membuktikan bahwa aplikasi $B$. subtilis B315 melalui perendaman benih umbi kentang mampu menunda masa inkubasi selama 7 hari. Hal serupa juga dinyatakan oleh Hersanti et al. (2009) bahwa perlakuan $P$. fluorescens (Pf9) dan B. subtilis (Ba14) mampu memperlambat gejala layu bakteri pada kentang selama 3 hari lebih lama dibandingkan kontrol.

Tabel 2. Masa Inkubasi, kejadian penyakit dan efektivitas penekanan penyakit layu bakteri pada tanaman tomat setelah aplikasi $B$. subtilis dan $P$. fluoresce

\begin{tabular}{lccc}
\hline \multicolumn{1}{c}{ Perlakuan } & $\begin{array}{c}\text { Masa Inkubasi } \\
\text { (hari) }\end{array}$ & $\begin{array}{c}\text { Kejadian } \\
\text { Penyakit (\%) }\end{array}$ & $\begin{array}{c}\text { Efektivitas } \\
\text { Penekanan } \\
\text { Penyakit (\%) }\end{array}$ \\
\hline Kontrol (akuades) & $15,45 \mathrm{a}$ & $35,71 \mathrm{~d}$ & - \\
Bakterisida streptomycin sulfat 20\% & $21,16 \mathrm{~b}$ & $21,42 \mathrm{bc}$ & 40 \\
B. subtilis UB-ABS2 & $22,50 \mathrm{bc}$ & $17,85 \mathrm{ab}$ & 50 \\
B. subtilis UB-ABS6 & $19,75 \mathrm{~b}$ & $25,00 \mathrm{c}$ & 30 \\
P. fluorescens UB-PF5 & $25,50 \mathrm{c}$ & $14,28 \mathrm{a}$ & 60 \\
P. fluorescens UB-PF6 & $25,50 \mathrm{c}$ & $14,28 \mathrm{a}$ & 60 \\
\hline
\end{tabular}

Keterangan : Angka yang diikuti huruf yang sama tidak berbeda nyata berdasarakan uji jarak berganda Duncan pada taraf $5 \%$.

Persentase penekanan kejadian penyakit layu bakteri di rumah kaca menunjukkan bahwa seluruh perlakuan agens hayati memperlihatkan kejadian penyakit yang lebih rendah dibandingkan dengan kontrol. Perlakuan $B$. subtilis UBABS2 dan $B$. subtilis UB-ABS6 menghasilkan persentase kejadian penyakit yang sama dengan perlakuan bakterisida. Perlakuan $P$. fluorescens UB-PF5 dan P. fluorescens UBPF6 menunjukkan persentase penekanan kejadian penyakit tertinggi yaitu sebesar 60\% (Tabel 2).

Perlakuan agens hayati pada tanaman tomat mampu menekan persentase kejadian penyakit layu bakteri dibandingkan hanya dengan penyiraman akuades. Hal ini diduga karena agens hayati yang diaplikasikan dapat mengkolonisasi perakaran dan melalui rangkaian mekanismenya mampu menghambat perkembangan $R$. solanacearum pada tanaman tomat. Bakteri agens hayati menghambat perkembangan patogen dengan beberapa mekanisme yaitu secara langsung dengan jalan menghasilkan berbagai senyawa metabolit anti patogen seperti siderophore, kitinase, antibiotik, dan sianida. Mekanisme secara tidak langsung 
yaitu memicu ketahanan terimbas atau Induksi Ketahanan Sistemik (ISR) pada tanaman inang (Chen et al., 2013). Hasil penelitian Istiqomah et al. (2017) menyatakan bahwa $B$. subtilis dan $P$. fluorescens mampu melarutkan fosfat dan memproduksi IAA (Indole Acetic Acid). Kedua zat ini dapat meningkatkan pertumbuhan dan kesehatan tanaman sehingga berimbas pada peningkatan ketahanan tanaman terhadap serangan patogen.

Ketahanan sistemik yang terbentuk dalam tanaman dapat diamati dengan menganalisa kandungan senyawa atau enzim penginduksi ketahanan seperti fenol dan peroksidase. Dalam penelitian ini, kandungan fenol pada tanaman tomat yang diberi perlakuan agens hayati lebih tinggi dibandingkan dengan kontrol kecuali pada B. subtilis UB-ABS2. Hal ini membuktikan bahwa salah satu mekanisme yang meningkatkan ketahanan tanaman tomat terhadap pernyakit layu bakteri adalah terbentuknya ketahanan sistemik tanaman melalui deteksi meningkatnya kadar fenol pada tanaman tomat.

\section{SIMPULAN}

Semua isolat $B$. subtilis dan $P$. fluorescens memiliki potensi menghambat $R$. solanacearum pada uji antagonis dengan tipe antibiosis bakteriostatik. Perlakuan $B$. subtilis UB-ABS6, $P$. fluorescens UB-PF5, dan $P$. fluorescens UB-PF6 mampu meningkatkan kadar fenol tanaman tomat. Aplikasi semua isolat agens hayati mampu menghambat masa inkubasi dan menekan kejadian penyakit layu bakteri pada tanaman tomat dengan efektifitas penekanan $30-60 \%$.

\section{DAFTAR PUSTAKA}

Abadi, A. L. (2003). Ilmu penyakit tumbuhan. Malang: Bayumedia Publishing.

Agrios, G. N. (2005). Plant diseases caused by viruses. In Plant Pathology. Fifth Edition. Elsevier Academia Press (pp. 724-820).

Champoiseau, P. G., Jones, J. B., \& Allen, C. (2009). Ralstonia solanacearum race 3 biovar 2 causes tropical losses and temperate anxieties. Plant Health Progress, 10, 1-10. doi:10.1094/PHP2009-0313-01-RV

Chen, Y., Yan, F., Chai, Y., Liu, H., Kolter, R., Losick, R., \& Guo, J. (2013). Biocontrol of tomato wilt disease by Bacillus subtilis isolates from natural environments depends on conserved genes mediating biofilm formation. Environmental Microbiology, 15(3), 848-864. doi: 10.1111/j.14622920.2012.02860.x

Chowdhury, S. P., Hartmann, A., Gao, X., \& Borriss, R. (2015). Biocontrol mechanism by root-associated Bacillus amyloliquefaciens FZB42-a review. Frontiers in Microbiology, 6, 780. doi: $10.3389 /$ fmicb. 2015.00780

Djatmiko, H. A., Arwiyanto, T., Hadisutrisno, B., \& Sunarminto, B. H. (2007). Potensi tiga genus bakteri dari tiga rizosfer tanaman sebagai agensia pengendali hayati penyakit lincat. Jurnal IImu-IImu Pertanian Indonesia, 9(1). https://doi.org/10.31186/jipi.9.1.4047

Hersanti, H., Rupendi, R. T., Purnama, A., Hanudin, H., Marwoto, B., \& Gunawan, O. S. (2009). Penapisan Beberapa Isolat Pseudomonas fluorescens, Bacillus subtilis dan Trichoderma harzianum yang bersifat 
Antagonistik terhadap Ralstonia solanacearum pada Tanaman Kentang. Agrikultura, 20(3).

Huang, J., Wei, Z., Tan, S., Mei, X., Yin, S., Shen, Q., \& Xu, Y. (2013). The rhizosphere soil of diseased tomato plants as a source for novel microorganisms to control bacterial wilt. Applied Soil Ecology, 72, 79-84. https://doi.org/10.1016/j.apsoil.2013. 05.017

Istiqomah, I., Aini, L. Q., \& Abadi, A. L. (2017). Kemampuan Bacillus subtilis dan Pseudomonas fluorescens dalam melarutkan fosfat dan memproduksi hormon IAA (Indole Acetic Acid) untuk meningkatkan pertumbuhan tanaman tomat. Buana Sains, 17(1), 75-84.

Kawaguchi, A., Inoue, K., \& Ichinose, Y. (2008). Biological control of crown gall of grapevine, rose, and tomato by nonpathogenic Agrobacterium vitis strain VAR03-1. Phytopathology, 98(11), 1218-1225. https://doi.org/10.1094/PHYTO-9811-1218

Ngadze, E., Icishahayo, D., Coutinho, T. A., \& Van der Waals, J. E. (2012). Role of polyphenol oxidase, peroxidase, phenylalanine ammonia lyase, chlorogenic acid, and total soluble phenols in resistance of potatoes to soft rot. Plant Disease, 96(2), 186192. https://doi.org/10.1094/PDIS02-11-0149

Nurcahyani, E., Sumardi, I., Hadisutrisno, B., \& Suharyanto, E. (2013). Penekanan perkembangan penyakit busuk batang vanili (fusarium oxysporum f. sp. vanillae) melalui seleksi asam fusarat secara in vitro. Jurnal Hama Dan Penyakit Tumbuhan Tropika, 12(1), 12-22. http://dx.doi.org/10.23960/j.hptt.112 12-22

Prashar, P., Kapoor, N., \& Sachdeva, S.
(2013). Isolation and Characterization of Bacillus $\mathrm{sp}$ with In-vitro Antagonistic Activity against Fusarium oxysporum from Rhizosphere of Tomato. Journal of Agricultural Science and Technology, 15, 15011512.

Prihatiningsih, N., Arwiyanto, T., Hadisutrisno, B., \& Widada, J. (2015). Mekanisme antibiosis Bacillus subtilis B315 untuk pengendalian penyakit layu bakteri kentang. Jurnal Hama Dan Penyakit Tumbuhan Tropika, 15(1), 64-71.

Rivard, C. L., O'connell, S., Peet, M. M., Welker, R. M., \& Louws, F. J. (2012). Grafting tomato to manage bacterial wilt caused by Ralstonia solanacearum in the southeastern United States. Plant Disease, 96(7), 973-978. https://doi.org/10.1094/PDIS-12-100877

Setiati, Y., N, H, Mutmainah., dan M, Subandi. (2016). Efektivitas jumlah telur Corcyra cephalonica terparasitasi Trichogramma sp. terhadap presentasi telur yang terparasit dan jumlah larva penggerek batang tebu bergaris (Chilo sacchariphagus). Jurnal Agro, III(1), 43-48. https://doi.org/10.15575/811

Sharma, G. N., Dubey, S. K., Sati, N., \& Sanadya, J. (2011). Phytochemical screening and estimation of total phenolic content in Aegle marmelos seeds. International Journal of Pharmaceutical and Clinical Research, 3(2), 27-29.

$\begin{array}{ccc}\text { Soesanto, L. } & \text { (2008). } & \text { Pengantar } \\ \text { pengendalian hayati } & \text { penyakit } \\ \text { tanaman. In PT Raja } & \text { Grafindo } \\ \text { Persada. Jakarta (p. 574). } & \end{array}$

Wahyudi, A. T., Meliah, S., \& Nawangsih, A. A. (2011). Xanthomonas oryzae pv. oryzae bakteri penyebab hawar daun pada padi: isolasi, karakterisasi, dan 
telaah mutagenesis dengan transposon. Makara Journal of Science.

https://doi.org/10.7454/mss.v15i1.88 5

Wati, F. D. A., Nurcahyanti, S. D., \& Addy, H. S. (2017). Eksplorasi Bacillus spp., dari perakaran kubis sebagai agen antagonis Xanthomonas campestris pv. campestris. Agritrop: Jurnal IlmuIlmu Pertanian (Journal of Agricultural Science), 15(2).
Weller, D. M., Mavrodi, D. V, van Pelt, J. A., Pieterse, C. M. J., van Loon, L. C., \& Bakker, P. A. H. M. (2012). Induced systemic resistance in Arabidopsis thaliana against Pseudomonas syringae pv. tomato by 2, 4diacetylphloroglucinol-producing Pseudomonas fluorescens. Phytopathology, 102(4), 403-412. https://doi.org/10.1094/PHYTO-0811-0222 